\title{
Using Video Cases and Small-scale Research Projects to Explore Prospective Mathematics Teachers' Noticing of Student Thinking
}

\author{
Fadime Ulusoy ${ }^{1 *}$, Erdinç Çakıroğlu ${ }^{2}$ \\ ${ }^{1}$ Kastamonu University, Faculty of Education, Kastamonu, TURKEY \\ ${ }^{2}$ Middle East Technical University, Ankara, TURKEY
}

Received 13 December 2017 - Revised 5 March 2018 - Accepted 5 March 2018

\begin{abstract}
This study investigated how prospective teachers notice student mathematical thinking in a video-based learning environment and in analyzing students' thinking when they conduct a research in their practice schools in the scope of a 14-week elective course program. Instructional process of the course had two phases. In the first phase, a group of eight prospective mathematics teachers analysed video cases related to students' mathematical thinking. In the second phase, they explored actual students' mathematical thinking through diagnostic interviews in their practice schools in order to conduct a small-scale research project. The results indicated that while prospective teachers tended to be more simplistic in analysing students' thinking in their early video-case analyses, they came up with deeper analysis of student thinking by making sound inferences from data and proposing pedagogical strategies. Moreover, prospective teachers stated that micro-case videos functioned as a catalyst for enhancing their noticing of student thinking before conducting small-scale research projects.
\end{abstract}

Keywords: video cases, noticing of student mathematical thinking, prospective teacher education, small-scale research projects

\section{INTRODUCTION}

Reform-based approach for teacher education encourages teachers to listen to students' ideas carefully and utilize those ideas in order to make appropriate pedagogical decisions (Ball, Lubienski, \& Mewborn, 2001; National Council of Teachers of Mathematics [NCTM], 2014). However, it can be challenging for prospective teachers to identify details of a student's idea if the idea is not clearly communicated in a classroom practice (Crespo, 2000; Sherin \& van Es, 2009). At this point, researchers think that it is necessary to design effective teacher education programs before prospective teachers actively enter to professional occupations at schools (Harrington, 1999; Shulman, 1992). In this sense, many researchers suggest that teachers need to "learn to notice" in order to attend to student thinking, to develop better pedagogical decisions for increasing students' learning (Goldsmith \& Seago, 2011; Jacobs, Lamb, \& Philipp, 2010; Sherin \& van Es, 2009; Star \& Strickland, 2008; van Es \& Sherin, 2002). However, researchers argue that prospective teachers do not develop their noticing of student mathematical thinking naturally (Stockero, Rupnow, \& Pasceo, 2017; Teuscher, Leatham, \& Peterson, 2017), but they can learn it (PhelpsGregory \& Spitzer, 2018; Stockero, 2014).

In recent years, researchers have begun to use video cases to support prospective teachers' noticing of student thinking (McDuffie et al., 2014; Mitchell \& Marin, 2015; Santagata, Zannoni, \& Stigler, 2007; Schack et al., 2013). They argue that video cases afford more time for teachers to attend, interpret, and respond to what they are observing with a narrower and more focused ways of classroom interactions within a learning community. In this sense, there is a variety of types of video used in teacher education such as commercially produced videos, teachers' own classroom videos and other teachers' classroom videos. However, some researchers reported that prospective teachers have great difficulties in learning to notice student thinking in classroom videos (Peterson \& Leatham, 2009; Stockero, 2008; Stockero et al., 2017; Superfine, Li, Bragelman, \& Fisher, 2015). Further, several reasons are

(C) 2018 by the authors; licensee Modestum Ltd., UK. This article is an open access article distributed under the terms and conditions of the Creative Commons Attribution License (http://creativecommons.org/licenses/by/4.0/). $\square$ fadimebayik@gmail.com (*Correspondence) $\square$ erdinc@metu.edu.tr 


\section{Contribution of this paper to the literature}

- This paper highlights the contributions of a course that integrates video cases and small-scale projects in order to understand prospective teachers' noticing of student mathematical thinking.

- Considering the limitations of classroom videos, this study showed that "micro-case videos" can be used an alternative effective approach to promote prospective teachers' noticing abilities by enabling them to directly attend to students' mathematical thinking and to interpret students' strategies.

- This paper demonstrated that the joint use of micro-case videos and small-scale research projects in the scope of a course can be a model for teacher preparation to answer the question of how university-based courses and field experience.

proposed for the difficulty that teachers encounter when eliciting and using student thinking in a classroom: (a) student thinking is not always articulated in classroom clearly (Freese, 2006; Mitchell \& Marin, 2015) and (b) teachers tend to notice various aspects of classroom environment like classroom management and climate (Sherin, Jacobs, \& Philipp, 2011; Star \& Strickland, 2008; van Es \& Sherin, 2008). Namely, it seems difficult for a prospective teacher to notice both noteworthy events about student mathematical thinking in a classroom video and interpreting them. Thus, crucial details about student thinking can remain unnoticed when a prospective teacher analyzes full-length classroom videos (Peterson \& Leatham, 2009; Stockero \& Van Zoest, 2013).

The complexity of video clips in terms of the events related to teaching and learning is particularly important for prospective teachers who often struggle with to pay attention to student mathematical thinking in video (Jacobs et al., 2010). In a recent study, Superfine, Fisher, Bragelman and Amodor (2017) developed a framework for examining the complexity of the salient teaching and learning events in video cases. They edited classroom videos based on student mathematical thinking. They called nonmathematical or non-pedagogical aspects of video cases noise. Furthermore, they conclude that the noisiness of a video clip is crucial for the development of novices' professional noticing abilities. At this point, considering the limitations of classroom videos in terms of capturing and editing events about student mathematical thinking in classroom environment, we think that producing and using micro-case videos that purely reflect students' mathematical thinking can be used an alternative effective approach to promote prospective teachers' noticing abilities. We defined micro-case video clips (MCVCs) as specially developed educational video cases that involve a collection of significant events related to an individual's thinking process on particular concepts or problem situations. In that process, the learner works on structured contentrelated tasks in isolated non-classroom environments. Just like "microscopes", micro-case videos can allow zooming in students' ideas deeply. In this way, micro-case videos might afford the opportunity to receive various students' thinking, and to compare and contrast different thinking processes. Furthermore, little is known about the nature and development of PTs' noticing of student thinking over time in purposeful ways by using video cases (van Es, Cashen, Barnhart, \& Auger, 2017) although it is suggested that teacher education programs should provide opportunities for prospective teachers to improve their knowledge and noticing skills (Kılıç \& Tunç-Pekkan, 2017; Roller, 2016; van Es et al., 2017). In line with this suggestion, we produce and use micro case videos to explore prospective middle school teachers' noticing of student mathematical thinking in the scope of an undergraduate course.

In prospective teacher education programs, it is important to build a connection between university-based courses and fieldwork in order to lessen the separation between theory and practice in the context of professional education (Darling-Hammond, 2006; Grossman et al., 2009). In this sense, teacher education programs in different countries have attempted to engage prospective teachers in research to support their learning since the 1950s (Beckman, 1957; Cochran-Smith, Barnatt, Friedman, \& Pine, 2009; Hiebert, Morris, Berk, \& Jansen, 2007). In this sense, Hammerness, Darling-Hammond and Bransfor (2005) argue that the prospective teachers, intensively participating in research activities in teacher training programs, fell more prepared and they are evaluated positively by their employers. As for the small-scale research projects of prospective teachers, it has been argued that conducting research related to their profession has considerable benefits for the professional development of prospective teachers (Cochran-Smith, 2003; Dobber et al., 2012). Dobber et al. (2012) point out that "conducting research is described as a promising activity in educating student teachers, but only when it is done in a purposeful, deliberate and reflective way, embedded in a program that highlights the inquiry of teaching as a continuous part of practice" (pp.609-610). From this perspective, the current study conjectured that small-scale research that prospective teachers would conduct in their practice schools might help to build a bridge between theoretical knowledge and practice, as well as to deepen their noticing within the scope of their own research questions. However, many studies have reported that prospective teachers find it very difficult to conduct research (e.g. Atay, 2008; Lunenberg, Ponte, \& van de Ven, 2007). In this study, prospective teachers were asked to conduct diagnostic interviews (Moyer \& Milewicz, 2002) with students in schools and analyze their data. Taking into account prospective teachers' limited skills and background in analyzing students' thinking, we used micro-case videos as a scaffold to help prospective teachers learn about to notice students' mathematical thinking and realize the need 
for in-depth elaboration of students' mathematical work to develop an understanding of students' thinking. From this point of view, we attempted to organize an undergraduate course in order to explore how prospective teachers notice student mathematical thinking in a video-based learning environment and in analyzing students' thinking when they conduct a research in their practice schools. Thus, the course was prepared in two phases: (i) investigation of middle school students' mathematical thinking through analysis of micro-case videos and (ii) conducting small-scale research projects for exploring students' mathematical thinking through interviews. This study, therefore, attempted to answer the following research questions: (1) To what extend do prospective middle school mathematics teachers notice student mathematical thinking when analyzing micro-case video clips and conducting small-scale research projects? (2) What kinds of perceptions regarding the role of analyzing micro-case videos on the noticing of students' mathematical thinking during small-scale research process do prospective teachers develop?

\section{Incorporating Prospective Teachers into Small-scale Research Projects}

Incorporating research into teacher education aims to encourage prospective teachers to engage in critical reflection, develop a questioning stance, construct new curricula and pedagogy and modify instruction to meet students' needs in student-centered pedagogy (Cochran-Smith et al., 2009; Parkinson, 2009; Souto-Manning, 2012). However, becoming a teacher researcher is long process and it is necessary to benefit from the support of the researchers at universities and collaboration of colleagues (Dobber et al., 2012). More specifically, researchers in social sciences begin to see small-scale research projects as part of an academic course at university and teachers' professional developments (Denscombe, 2010). For social studies, Knight (2001) define small-scale research as systematic inquiries that involve one person, little or no funding and a fairly short period of time to complete the inquiry and report (p. xi). Munthe and Rogne (2015) explain small-scale research as "a way to learn methods and thinking in concert with a miniature research project" (p.22). Conducting small-scale projects contributes to the development of teachers' knowledge (Ponte, Ax, Beijaard, \& Wubbels, 2004). Thus, teachers can understand what works and why it works in practice. Considering the affordances of the use small-scale projects, various studies have been conducted in order to incorporate teachers in research in different countries. In these studies, it is reported that conducting small-scale research projects provides opportunities to teachers to develop new insights about the research process (Gray, 2013; Trent, 2010), about their selected topic (Goodnough, 2010; MegowanRomanowicz, 2010), and about their own inquiry process as a practitioner (Freese, 2006; Reis-Jorge, 2007). According to Parkinson (2009), prospective teachers shift their perceptions about the role and needs of students when they are engaged in collaborative action research during teacher education. However, there is limited number of studies on how prospective teachers experience research during teacher education program (Healey \& Jenkins, 2009). For this reason, in this study, we aimed to understand how prospective teachers notice student thinking when they are engaged in a small-scale research project.

\section{METHODOLOGY}

In this research, an exploratory case study was used to examine the nature of prospective teacher' noticing abilities when they analyze students' mathematical thinking in MCVCs and conducting a small-scale project. It is considered exploratory because of the scarcity of studies that explore prospective teachers' noticing abilities by using both video cases and research-based approach in the scope of an undergraduate course. In this sense, this study provides an in-depth examination of how prospective teachers think and reason with respect to professional noticing and how they conceptualized their ability to notice through MCVCs. Furthermore, this study was evaluated as an attempt to lay the groundwork that will lead to future studies related to noticing of student mathematical thinking.

\section{Context and Participants}

The context of the study is an undergraduate mathematics teacher education program at a public university in Ankara, Turkey. Graduates of the program are qualified to be mathematics teachers in middle schools, from grade 4 to grade 8 (ages 10-14). The program offers courses related to mathematical content, general education, and mathematics education. This study was designed as a 14-week elective course program with the purpose of providing opportunities for PTs examine student thinking in videos and gain experience in designing and conducting a project in order to deepen knowledge about student thinking. In a qualitative study, researchers generally select participants based on their purpose in order to examine the situations in more detail. In this regard, the participants were selected by using purposive sampling method for obtaining deep and detailed information. Eight female prospective teachers were enrolled in the elective course. Specifically, maximum variation sampling method was used to select participants of the study to understand how different achievement level students notice student mathematical thinking. Their academic achievement levels were differing. Emel and Maya had CGPAs 
(Cumulative Graduate Point Average)) between 3.50 and 4.00. Beril, Oya, Zehra, Ece had CGPAs between 3.00-3.50 and Eda and Deniz had CGPAs between 2.00-2.50. Furthermore, all participants were selected from the prospective teachers who completed pure mathematical courses and most of their required educational courses such as methods of teaching mathematics and school experience. In the same semester with this study, all of the participants were enrolled in a research methods and a field experience course, where they did observation and student teaching in schools.

\section{Micro-case Video Production}

MCVCs involved a collection of specially selected and edited events about middle school students' mathematical thinking on basic geometric concepts and quadrilaterals. We selected concepts related to quadrilaterals as a focus in the MCVCs, because quadrilaterals are relatively well-researched in Turkish context, which was considered as an advantage in producing relevant micro-cases for the study. In order to produce MCVCs, we conducted case production interviews with 16 seventh grade students. Then, 1000 minutes raw video data obtained. In the literature, researchers generally do not use video cases more than ten minutes (e.g. Seago, 2004; Sherin, Linsenmeier, \& van Es, 2009) because they found long videos ineffective in terms of providing a productive video discussion. For this reason, the duration of MCVCs ranged from 4 to 10 minutes and involved a collection of specially selected and edited events about individual seventh grade students' mathematical thinking on definitions, constructions, and understanding of hierarchical relations related to quadrilaterals. Two segments from MCVC1 involving a moderate achiever student's thinking about parallelogram are presented in Appendix 1.

\section{Design and Implementation of the Course}

The elective course involved two main phases (see Figure 1). In the first phase, the participants analyzed and discussed middle school students' conceptions through the medium of MCVCs for eight video sessions. The main activity of the first phase was to analyze and discuss middle school students' mathematical thinking in MCVCs in 8 sessions through 4 weeks. In each video session, the participants first individually analyzed a MCVC and wrote a reflection paper related to the student's mathematical thinking in the given video. In these reflection papers, they were asked to write about (i) what they noticed in student's mathematical thinking process, (ii) what they thought about possible reasons for student's conceptions/misconceptions/difficulties on quadrilaterals, and (iii) what kinds of instructional strategies they would use or propose to overcome student's misconceptions/difficulties in the video.
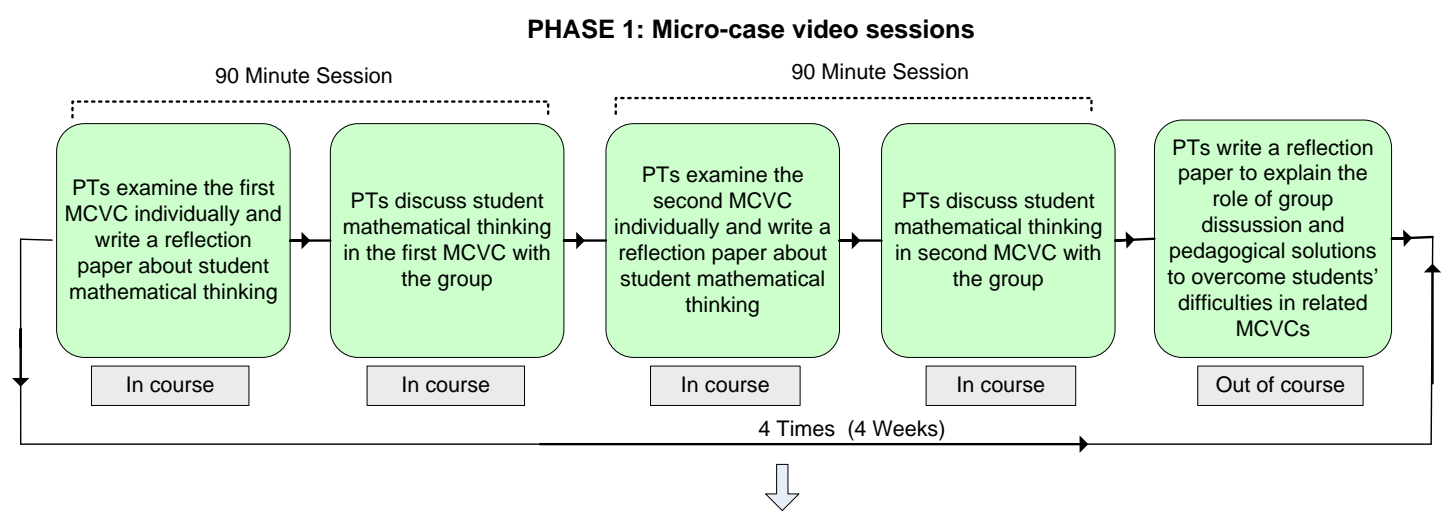

PHASE 2: Small-scale research project process

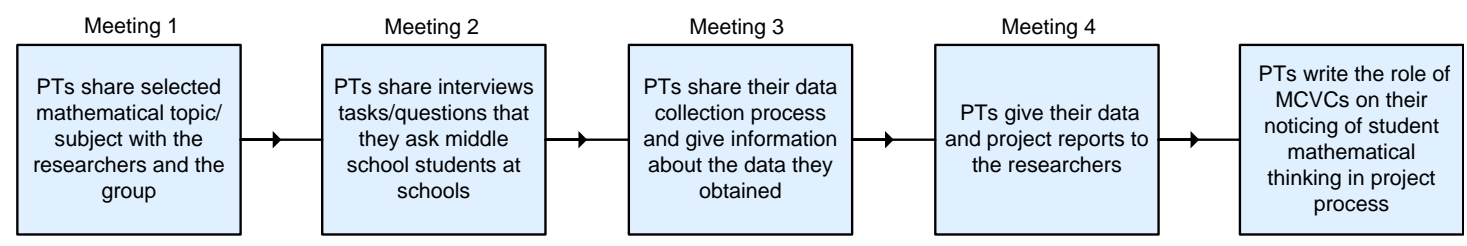

Figure 1. The main components of video sessions and small-scale research project process for prospective teachers when working on students' mathematical thinking

After individual video analysis, a group discussion was initiated for the related MCVC by using a framework developed for the facilitation of the video-based discussion (van Es, Tunney, Goldsmith \& Seago, 2014). In group 
discussions, researchers had the roles of (i) orienting the group to the video analysis task (e.g. "What did you notice in the video?" and "What did you find interesting in the video?"), (ii) sustaining an inquiry stance (e.g. "Can you tell me more about that?" and "I understood your idea. Can you give some details what you exactly mean?"), (iii) maintaining focus on the video and the mathematics (e.g. "What your strategies are if your students would do same mistakes in your class?"), and (iv) supporting group collaboration (e.g., "That is really interesting. I had not thought that before." And "That seems reasonable, but that could be another interpretation."). After the group discussion, we requested the participants to write an "after-discussion reflection". In these reflection papers, we asked them to propose specific recommendations for helping the difficulties of students they observed in the video cases and to explain how they influenced their peers' ideas about student thinking.

In the second phase of the course, the participants were guided to conduct a small-scale research project for indepth exploration of actual students' mathematical thinking in their practice schools, on a mathematical concept they chose, within the scope of research questions formulated by them. The steps of this phase illustrated in Figure 1. In this sense, they selected mathematical concepts/topics and determined their research aims to be studied. After that, they shared them in the classroom and getting feedback from peers and the researchers in the first meeting. The mathematical concepts participants selected for studying include numbers (least common multiple-greatest common divisor, decimals, exponents, and integers), geometry (the altitude of a triangle, line symmetry) and measurement (area of quadrilaterals and area of polygons). The prospective teachers selected 2 to 4 students to conduct diagnostic interviews. Five PTs selected students in different performing mathematics levels (e.g. highmedium-low) based on their mathematics grades taken in previous semesters and their mathematics teachers' opinions. Furthermore, three PTs decided to select low performing students in mathematics in same way. Then, they began to prepare the tasks/interview questions to be asked to the students and shared them in the lesson and getting feedback from peers and the researchers in the second meeting. In the following, they conducted diagnostic interviews with the students in a middle school. They recorded interview process with a voice recorder to examine students' mathematical thinking. They also used students' written works on the tasks as a data source. In the third meeting, they shared their preliminary insights. Finally, they wrote their own project report and they shared data analysis processes and the results of their studies in the classroom. At the end of the course, they wrote a 'selfdevelopment paper' in which they wrote about their perceptions regarding the role of analyzing micro-case videos on their noticing of student mathematical thinking in their small-scale research process.

\section{Data Sources}

In this study, it is benefited from multiple data sources: (1) individual clinical interviews, which were administered at the beginning and at the end of the course to the prospective teachers, and included questions that aim to understand PTs' subject matter knowledge and pedagogical content knowledge on quadrilaterals; (2) PTs' individual written reflection papers for each MCVC; (3) PTs' group discussions of the MCVCs; (4) PTs' individual reflection papers written after group discussion in each week. Another source (5) was video and audio-recorded video sessions, and field notes. In addition, each classroom meeting in project process is another source (6) of the data. In that process, the researchers noted all noteworthy points related to PTs' noticing of student thinking. Furthermore, PTs' project reports (7) are another important data source. The final source (8) was individually written reflection papers on the process of PTs' own noticing of student thinking and their experiences in implementing the small-scale projects in their practice school after the first phase of the course.

\section{Data Analysis}

Data analysis was conducted in two phases related to the two research questions. In order to determine how prospective middle school mathematics teachers notice students' mathematical thinking in MCVCs and projects reports we examined data of data obtained in videos sessions including reflection papers and group discussion and research reports. When coding the data, the adapted version of van Es's (2011) framework related to learning to notice student thinking was used. This framework has two dimensions: "what teachers notice" and "how teachers analyze what they notice". In this study, the main focus was the second dimension because MCVCs involves only students' mathematical thinking instead of a classroom environment. Thus, it is aimed to understand the analytic stance and level of depth of participants' noticing of students' mathematical thinking in the video sessions and in their research project reports. Analytic stance refers to the ways teachers use to analyze student thinking in MCVCs (e.g. restating, describing, evaluating, interpreting, inferring, and suggesting). On the other hand, the depth of analysis refers to whether the prospective teachers "provide few details to explain their thinking or ground their comments in evidence and elaborate on their analyses" (van Es, 2011, p. 138).

The framework used in the analysis has 4 levels to show how teachers notice student thinking. The participants' comments and written statements were recorded as Level 1, "baseline", if they exclusively describe students" actions/thoughts with general and surface statements providing little or no evidence to support their analysis (e.g. 
“The student firstly defined parallelogram and then drew two examples. She drew a regular hexagon to illustrate parallelogram."). At Level 2, "mixed" level, participants are still giving general impressions by starting to point out remarkable events in student thinking. They also evaluate what they observe and attempt to give a meaning to what they noticed. Furthermore, they mention particular examples to give evidence or support their interpretations. In this sense, they provide evaluative statements and a few interpretive comments on student thinking (e.g. "The student knows the concept of the parallelogram roughly. The definition [made by the student] is acceptable and parallelogram figures drawn are correct. However, the student had some misconceptions."). At Level 3, "focused" level, the participants try to make inferences about their observations. In this sense, they use their observations to make hypotheses on why these events were taking place (e.g. "Student concentrated on prototypical examples. This might be related to the examples that their teachers used in the lessons."). Finally, at Level 4, "extended" level, they build additional ideas to Level 3. They propose alternative teaching approaches on the basis of their analysis. Upon analysis of student thinking, they also revisit the tasks in the curriculum and examine how they help or hinder students (e.g. "...It is useful to prepare a student-centered activity in which there are examples of parallelograms to overcome students' difficulties."). Two researchers independently coded participants' comments in randomlyselected $20 \%$ sample of responses in terms of the four categories. Agreement reached at least $80 \%$ among coders on all items. Furthermore, any discrepancy between the experts analysis were discussed until consensus was reached.

For the second research question, participants' self-development papers and comments in course meetings were examined by using open-coding, axial coding and selective coding techniques of grounded theory (Strauss \& Corbin, 1998), looking for patterns within and across participants' comments in order to identify themes about perceived roles of MCVCs on the participants' noticing of student thinking in the research project process. Specifically, participants' comments were grouped in order to identify themes. Evidence to support and/or negate each theme was pulled from the data to establish a clear pattern in participants' comments. The final phase of analysis involved looking for patterns across the teachers' perceptions.

According to Merriam (1998), there are six basic strategies to enhance internal validity in a qualitative study: Triangulation-using multiple sources, multiple investigators, or multiple methods, member checks, long-term observation, peer examination, participatory or collaborative modes of research and research's biases. In the current study, most of these methods were utilized to provide and increase credibility. The second criteria to establish trustworthiness in a qualitative study is transferability referring to external validity. Transferability was used by ensuring sufficient information about implementation processes in qualitative research. Thus, it was provided thick description of the study so that the reader understands it and compare to their own studies. For this research, the context of the study, the selection criteria of the participants, the number of participants, the purpose and context of any instrument to be used in the study, the number of the length of the data collection sessions, and the time period of the study will be explained in detail for ensuring the transferability.

\section{FINDINGS}

\section{The Nature of Prospective Teachers' Noticing of Student Mathematical Thinking in Micro-case Video Sessions}

In order to determine the level of prospective mathematics teachers' noticing of students' mathematical thinking during the micro-case video analysis sessions we analyzed their early and late individual video analysis reflection papers that were written in the first phase of the course (see Table 1).

Table 1. The nature of participants' comments in video sessions

\begin{tabular}{ccccc}
\hline \multirow{2}{*}{ PTs } & \multicolumn{2}{c}{ Early video sessions } & \multicolumn{2}{c}{ Late video sessions } \\
\cline { 2 - 5 } & $\mathbf{1}^{\text {st }}$ session & $\mathbf{2}^{\text {nd }}$ session & $\mathbf{7}^{\text {th }}$ session & $\mathbf{8}^{\text {th }}$ session \\
\hline Beril & Baseline-L1 & Mixed-L2 & Focused-L3 & Focused-L3 \\
\hline Ece & Mixed-L2 & Mixed-L2 & Focused-L3 & Focused-L3 \\
\hline Aslı & Baseline-L1 & Mixed-L2 & Extended-L4 & Extended-L4 \\
\hline Emel & Mixed-L2 & Mixed-L2 & Focused-L3 & Extended-L4 \\
\hline Oya & Mixed-L2 & Focused-L3 & Focused-L3 & Focused-L3 \\
\hline Maya & Focused-L3 & Focused-L3 & Extended-L4 & Extended-L4 \\
\hline Zehra & Focused-L3 & Focused-L3 & Extended-L4 & Extended-L4 \\
\hline Deniz & Baseline-L1 & Baseline-L1 & Focused-L3 & Focused-L3 \\
\hline
\end{tabular}

Table 1 showed that participants provided different explanations at various levels in terms of understanding students' mathematical thinking. More specifically, at the baseline level, Asli and Deniz tended to give only brief descriptions of student thinking in video cases instead of paying attention to the details of students' thinking. Thus, 
they offered general and surface features of student thinking in micro-case videos. One example of such comments included:

The student started with the definition of parallelogram and she said that a parallelogram would have 4 edges, but she did not use the information. The student drew two parallel line segments as a parallelogram example. She had difficulty when drawing parallelogram to have four edges. When choosing the parallelograms, the student considered only the opposite edges to be parallel. The student might have misconceptions (about parallelogram)... [Ash, reflection paper-MCVC1].

Asli chronologically described all the actions of the student in the video, instead of explaining the possible reasons why the student drew two parallel line segments as an example of parallelogram. She did not provide evidences to support her idea. Besides, Beril, Oya, and Ece used evaluative comments about the events in videos in addition to general impressions. In this regard, they generally focused on the correctness of student's responses in the early video analysis sessions. However they did not interpret why the student made an incorrect definition, construction or explanation about quadrilateral. For example, Beril made the following comments in her reflection paper:

The student does not have enough knowledge about parallelogram. Furthermore, the student incorrectly defined and drew parallelogram. She provided inconsistent explanations throughout the video. This has shown that students do not exactly know even if the concept seemed to be very simple... [Beril, reflection paper-MCVC1].

Beril's explanations were based on evaluating students' answers in terms of accuracy and consistency, but she highlighted significant events about student's mathematical thinking in the video to support her inference. Differently, Emel, Zehra and Maya made interpretive and analytical comments about the events in the early video cases with some inferences. In this regard, participants examined specific events from the clips and used these details to make inferences about student thinking. Their comments indicated that they linked the student's definitional error with various reasons rather than evaluating its correctness only in MCVC1. For instance, Zehra inferred that the student could not differentiate between "corner points" and "sides of parallelogram" and also the student was not aware of the "closedness" property of quadrilaterals by drawing attention to the inconsistency between the student's verbal and written descriptions in MCVC1. In sum, individual video analysis reflection papers written for early video analyses indicated that the participants were at different levels in terms of interpreting student mathematical thinking. On the other hand, the comments in the late individual video analysis reflections showed that all prospective teachers, excluding Emel, increased their noticing levels in terms of understanding student mathematical thinking even when they were at baseline level or focused level in early reflections.

In their project reports at the end of the second phase, prospective teachers' comments indicated that they could analyze students' mathematical thinking at the "extended" level. The following statements in Beril's project report provide an example regarding the participants' interpretive/suggestive explanations on students' mathematical thinking:

\begin{abstract}
...In the interviews, the students could easily find symmetry of shapes with respect to a vertical line rather than a horizontal line. However, they had difficulties when finding symmetry of shapes according to an inclined line. This can stem from students' inadequate knowledge of symmetry and ability to construct equal length line segments. I think that another possible reason might be related to examples that teachers used while teaching line symmetry. Most probably, their teacher only concentrated on line symmetry according to vertical/horizontal axes instead of an inclined line...I suggest that teachers use different materials such as daily life examples, architectural structures, symmetry mirror, folding paper activities and technological applications when teaching symmetry... [Beril, project report].
\end{abstract}

Above excerpt indicated how a prospective teacher focused on significant mathematical details in students' thoughts/actions by making inferences, providing possible alternative explanations, or evidence to support her explanations, and clarifying the reasons behind students' incorrect responses, constructions or solutions in her project report while she only evaluated the correctness of students' responses in early video sessions. Another example was given from Maya's project report in the following:

...In order to understand students' conceptions about altitude of triangle, I asked questions about the concepts of angle, triangle, and altitude. Probably because students had inadequate knowledge on angle and altitude concepts, they may not draw altitude of different triangles correctly. This highlights the importance of addressing prerequisites of a concept to assess students' conceptions completely. I believe 
that the examples and activities teacher use are important to overcome such problems. I think that it can be useful to prepare some activities on basic geometric concepts in grid papers before teaching altitude of triangles... [Maya, project report].

In her project report, Maya not only described students' difficulties in altitude of triangles but also established a relation among students' incomplete understandings and their lack of knowledge in basic geometric concepts. She also considered the relationship between student thinking and teachers' pedagogy. On the basis of her interpretations, she offered alternative pedagogical solutions. Such comments carry the characteristics of the "extended" noticing level.

In conclusion, prospective teachers did not solely describe students' responses or used judgmental statements as "correct" and "incorrect" in their research projects. They focused on the details of students' mathematical thinking whatever mathematical topic, students' grade level, and students' mathematics achievement levels are. They provided a variety of explanations, examples or interpretations by pinpointing the data that directly exemplifies students' thinking, reactions, and representations. Moreover, they extended their analyses by establishing a relationship between student thinking and specific instructional strategies to overcome difficulties, errors, and misconceptions of students.

\title{
Perceived Roles of Analysing Micro-case Videos on Understanding of Students' Thinking in Small-scale Research Projects
}

When we examined the participants' perceptions about the role of analyzing MCVCs on their understanding of students' mathematical thinking in the organization of small-scale research projects, they proposed that analyzing MCVCs had various contributions to their project process in terms of: (i) anticipating, (ii) eliciting, and (iii) being more selective and interpretative about student thinking (see Table 2).

Table 2. Common perceptions about the role of analysing MCVCs

\begin{tabular}{llll}
\hline Phases of projects & $\begin{array}{l}\text { Common perceptions about the } \\
\text { role of analyzing MCVCs }\end{array}$ & Details of prospective teachers' perceptions \\
\hline \multirow{2}{*}{ Planning } & Anticipating student thinking & - & Selecting the concepts students have difficulties \\
& & - & Selecting students purposefully \\
\multirow{2}{*}{ Implementation } & Eliciting student thinking & - & Using why/how questions in interviews \\
\multirow{2}{*}{ Reporting } & Being selective and interpretative & - & Asking spontaneous probing questions \\
& about student thinking & - & Providing interpretative/suggestive comments \\
\hline
\end{tabular}

\section{Planning of projects-Anticipating student thinking}

All prospective teachers mentioned that they developed skills to anticipate various mathematical ways students might exhibit when they worked on the given mathematical tasks. In light of their anticipations, participants stated that they could purposefully select students for their projects and they could prepare conceptual tasks and questions to ask the students instead of using merely procedural ones. For instance,

\begin{abstract}
I had no experience to examine the details of student thinking in my practice courses or teaching method courses. To be honest, I did not try to figure out how students can answer our questions before this course. Before we watched the video, I thought that successful students would answer the questions asked correctly. However, I changed my mind because in the videos we watched I could see that all students can have various misconceptions. Moreover, a high achiever student could develop different strategies in the videos. For this reason, I chose different achievement level students for my project. I expected that the diversity of students' thoughts would help me obtain rich data. [Oya, selfdevelopment paper].
\end{abstract}

The participants' also emphasized that analysing MCVCs helped them to be more critical in organizing the interview tasks. They could develop ideas for interviews in which they seek production of various representations from students. For example, Maya stated the following:

After watching the videos, I understood that students' actual thinking ways can be very different than our initial thinking. I realized the correctness of students' written solutions did not guarantee the adequateness of their conceptions as we examined different videos. Thus, when preparing tasks, I focused on the questions assessing not only students' written solutions but also verbal expressions and 
representations in order to get detailed information about student thinking. [Maya, self-development paper].

Maya's perceptions indicate that she found MCVCs helpful in terms of considering possible student thinking during the preparation of her research project. In this regard, when preparing the tasks for her project, she anticipated that the reason for not being able to draw the altitude of an obtuse triangle might be due to students' lack of knowledge in basic concepts of "altitude" and "angle." Therefore, she prepared specific interview questions to elicit such kinds of prerequisite conceptions. As Maya's example demonstrated, even the prospective teachers who interpreted students' mathematical thinking in early video analyses expanded their skills and included their anticipations about student thinking in their research projects.

\section{Implementation of projects-Eliciting student thinking}

All participants stated that doing video analysis before conducting the projects helped them to learn what kinds of tasks/questions they could use to elicit students' thinking and to see different ways of asking 'how' and 'why' questions. An example excerpt is presented below:

In my project, I first thought about possible questions that I can ask to students about exponents. At that point, I recalled the students in the videos who had difficulties in basic geometric concepts. I recognized the importance of understanding students' prior conceptions about exponents and I asked questions about integers to assess students' background knowledge during the interviews. Furthermore, in the interviews, I generally asked why and how questions [Ash, meeting 3].

Asli's explanation clearly showed she developed an understanding about the importance of asking suitable questions to elicit students' background on mathematical concepts in her project. In this regard, she tried to understand what students know about operation with integers and the meaning of zero before directly asking questions about exponents and operations in her project. Not only Asli but also other participants included interview questions that explore students' background knowledge for a specific mathematical concept. They started to believe that questioning allows them to elicit students' thinking.

\section{Reporting of projects-Being selective and interpretative about student thinking}

The prospective teachers' comments in self-development papers also indicated that they believed that video analysis helped them to pay attention to students' ideas selectively when writing their research projects. The comments participants made in the meetings of the course and research reports supported these perceptions because they generally attended to critical points reflecting students' mathematical understanding in data instead of explaining what student made in the interviews chronologically. In other words, they stated that they questioned noteworthy events about student mathematical thinking instead of summarizing all actions of students. Maya's reflections can be an example to this point of view:

In individual [video] analysis, I tended to describe what happened in the video. However, video analyses
helped me to develop a deeper understanding of student thinking because I realized that attending to
student's all actions (in the video) is not useful. Thus, I focused on noteworthy events in my project.
For example, instead of assessing the correctness of students' definitions and constructions of triangles
only, I questioned the relationship between student's descriptions and constructions of triangles in my
project [Maya, self-development paper].

The prospective teachers also made numerous comments revealing that the video analysis enabled them to recognize and to question the underlying reasons behind students' difficulties and errors about mathematical concepts and to develop alternative pedagogical ways to overcome them. For example, Deniz stated that "I had opportunities to think how this student solved this problem or why she drew this figure incorrectly and how we can overcome students' difficulties with the help of video analyses." Deniz's comments showed that she considered video cases a catalyst for catching mathematical details of student thinking in her small-scale research project and developing awareness about various instructional ways to overcome the students' misunderstandings. In this regard, she highlighted teachers' instructional approaches, examples given in the textbooks, students' different thinking styles, and students' background knowledge as the possible reasons for learners' mathematical difficulties in her project report. 


\section{CONCLUSION AND DISCUSSION}

In the current study, we aimed to investigate prospective mathematics teachers' noticing of students' mathematical thinking in their small-scale research projects and to understand their perceptions about the role of analyzing micro-case video clips (MCVCs) on their interpretations of students' mathematical thinking. The results obtained in the first phase of this study revealed that the prospective teachers' interpretations of students' mathematical thinking progressed towards being more in-depth in nature, which is consistent with previous studies (Ingram, 2014; van Es, 2011). For example, the prospective teachers only described the events in the video case or simply checked the correctness of student's responses in the early video analyses. However, in the subsequent video analyses, all prospective teachers provided mathematically substantial descriptions instead of providing superficial descriptions of students' mathematical thinking. Thus, the findings confirmed that analyzing video-cases had the potential to provide promising opportunities for prospective teachers in terms of developing their knowledge of students' mathematical thinking (e.g. Walkoe, 2015). In the literature, researchers generally used classroom videos when examining teachers' noticing abilities (e.g. Sherin \& van Es, 2009; Star \& Strickland 2008; van Es, 2011). Such video-cases involve information about classroom learning environments which are complex in nature. Micro-case videos, on the other hand, focus on a learner's mathematical understanding as a "microscope" which enabled the prospective teachers to directly attend to students' mathematical thinking and to interpret students' strategies in almost all video meetings. Consequently, analysis of micro-case videos provided detailed and focused noticing on students' mathematical ideas in the current study.

Related literature emphasizes that prospective teachers need to know what a student might mean when making mathematical explanations, what questions to ask the student, and which student ideas are worth questioning to understand the underlying logic behind their ideas (Grossman et al., 2009; Moyer \& Milewich, 2002). In this regard, in light of the results, we argue that experiences gained in the first phase of the course are useful and they promote prospective teachers in the research (second) phase of the course. Throughout the course, we observed that working with MCVCs before incorporating prospective teachers into small-scale research enabled them to analyze students' mathematical thinking. They tended to design and carry out their projects carefully by anticipating possible student responses, eliciting students' thoughts, and interpreting students' mathematical thinking. Specifically, the results related to the perceived roles of analyzing MCVCs on conducting small-scale research projects indicated that MCVCs functioned as scaffolding for the development of prospective teachers' knowledge about student thinking before conducting small-scale research projects. By analyzing micro-cases, prospective teachers gained a much deeper and detailed viewpoint compared to their initial viewpoint about middle school students' mathematical thinking at the end of the second phase of the course. We explore that working on micro-case videos prior to conducting a small-scale research helps prospective teachers to gain essential experience and contributes to the different aspects of their research study. In this sense, we reach the conclusion that micro-case videos can be used as a catalyst to establish a strong and relevant knowledge on students' mathematical thinking by enabling them to enter each student's mathematical world. At this point, joint use of micro-case videos and small-scale research projects in the scope of a course can be a model for teacher preparation to answer the question of how universitybased courses and filed experience. Thus, prospective teachers and teacher educators can benefit from the opportunities to work and learn together about various aspects of student mathematical thinking in more detail. For this reason, we recommend that further studies focus on the in-depth role of micro-case videos on the development of prospective teachers' conceptions regarding various aspects of pedagogical content knowledge and noticing abilities.

In this research, studying the eight prospective teachers in an exploratory case study provided opportunities for careful examination of their noticing process individually. For this reason, these findings are not generalizable to all prospective teachers. However, this study provides an in-depth understanding of how these PTs professionally noticed, how they shifted in their noticing, and they conceptualized their noticing both in examining MCVCs and in conducting small-scale projects.

\section{REFERENCES}

Atay, D. (2008). Teacher research for professional development. ELT Journal, 62(2), 139-147. https:/ / doi.org/10.1093/elt/ccl053

Ball, D. L., Lubienski, S. T., \& Mewborn, D. S. (2001). Research on teaching mathematics: The unsolved problem of teachers' mathematical knowledge. Handbook of research on teaching, 4, 433-456.

Beckman, D. (1957). Student teachers learn by doing action research. Journal of Teacher Education, 8, 369-375. https:// doi.org/10.1177/002248715700800408

Cochran-Smith, M. (2003). The multiple meanings of multicultural teacher education: a conceptual framework. Teacher Education Quarterly, 30(2), 7-26. 
Cochran-Smith, M., Barnatt, J., Friedman, A., \& Pine, G. (2009). Inquiry on inquiry: practitioner research and students' learning. Action in Teacher Education, 31(2), 17-32. https:/ / doi.org/10.1080/01626620.2009.10463515

Crespo, S. (2000). Seeing more than right and wrong answers: Prospective teachers' interpretations of students' mathematical work. Journal of Mathematics Teacher Education, 3(2), 155-181. https://doi.org/10.1023/A:1009999016764

Darling-Hammond, L. (2006). Constructing 21st-century teacher education. Journal of Teacher Education, 57(3), 300314. https:// doi.org/10.1177/0022487105285962

Denscombe, M., 2010. The good research guide for small-scale social research projects. London, England: McGraw Hill. Open University Press.

Dobber, M., Akkerman, S. F., Verloop, N., \& Vermunt, J. D. (2012). Student teachers' collaborative research: Smallscale research projects during teacher education. Teaching and Teacher Education, 28(4), 609-617. https:// doi.org/10.1016/j.tate.2012.01.009

Freese, A. R. (2006). Reframing one's teaching: Discovering our teacher selves through reflection and inquiry. Teaching and Teacher Education, 22(1), 100-119. https:/ / doi.org/10.1016/j.tate.2005.07.003

Goldsmith, L. T., \& Seago, N. (2011). Using classroom artifacts to focus teachers' noticing: Affordances and opportunities. In M. G. Sherin, V. R. Jacobs, \& R. A. Philipp (Eds.), Mathematics teacher noticing: Seeing through teachers' eyes (pp. 169-187). London, England: Routlege.

Goodnough, K. (2010). The role of action research in transforming teacher identity: Modes of belonging and ecological perspectives. Educational Action Research, 18(2), 167-182. https:/ / doi.org/10.1080/09650791003740725

Gray, C. (2013). Bridging the teacher/researcher divide: Master's-level work in initial teacher education. European Journal of Teacher Education, 36(1), 24-38. https:/ / doi.org/10.1080/02619768.2012.682648

Grossman, P., Hammerness, K., \& McDonald, M. (2009). Redefining teaching, re-imagining teacher education. Teachers and Teaching: Theory and Practice, 15(2), 273-289. https:/ / doi.org/10.1080/13540600902875340

Hammerness, K., Darling-Hammond, L., \& Bransford, J. (2005). How teachers learn and develop. In L. DarlingHammond \& J. Bransford, (Eds.), Preparing teachers for a changing world: What teachers should learn and be able to do, (pp. 358-389). San Francisco, CA: Wiley \& Sons.

Harrington, H. L. (1999). Case analyses as a performance of thought. In M. A. Lundeberg, B. B. Levin, \& H. L. Harrington (Eds.), Who learns what from cases and how: The research base for teaching and learning with cases (pp. 29-48). Mahwah, NJ: Lawrence Erlbaum Associates.

Healey, M., \& Jenkins, A. (2009). Developing undergraduate research and inquiry. York: Higher Education Academy.

Hiebert, J., Morris, A. K., Berk, D., \& Jansen, A. (2007). Preparing teachers to learn from teaching. Journal of Teacher Education, 58(1), 47-61. https:/ / doi.org/10.1177/0022487106295726

Ingram, J. (2014). Supporting student teachers in developing and applying professional knowledge with videoed events. European Journal of Teacher Education, 37(1), 51-62. https:/ / doi.org/10.1080/02619768.2013.801074

Jacobs, V. R., Lamb, L. L. C., \& Philipp, R. A. (2010). Professional noticing of children's mathematical thinking. Journal for Research in Mathematics Education, 41(2), 169-202.

Kılıç, H., \& Pekkan, Z. T. (2017). University-school collaboration as a tool for promoting pre-service mathematics teachers' professional skills. International Journal of Research in Education and Science, 3(2), 383-394. https:/ / doi.org/10.21890/ijres.327897

Knight, P. T. (2001). Small-scale research: pragmatic inquiry in social science and the caring professions. London: Sage publications.

Lunenberg, M., Ponte, P., \& van de Ven, P. H. (2007). Why shouldn't teachers and teacher educators conduct research on their own practices? An epistemological exploration. European Educational Research Journal, 6(1), 13-23. https:/ / doi.org/10.2304/eerj.2007.6.1.13

McDuffie, A. R., Foote, M. Q., Bolson, C., Turner, E. E., Aguirre, J. M., Bartell, T. G., ... Land, T. (2014). Using video analysis to support prospective K-8 teachers' noticing of students' multiple mathematical knowledge bases. Journal of Mathematics Teacher Education, 17(3), 245-270. https:/ / doi.org/10.1007/s10857-013-9257-0

Megowan-Romanowicz, C. (2010). Inside out: Action research from the teacher-researcher perspective. Journal of Science Teacher Education, 21(8), 993-1011. https:/ / doi.org/10.1007/s10972-010-9214-Z

Merriam, S. B. (1998). Qualitative Research and Case Study Applications in Education. Revised and Expanded from" Case Study Research in Education." Jossey-Bass Publishers. 
Mitchell, R. N., \& Marin, K. A. (2015). Examining the use of a structured analysis framework to support prospective teacher noticing. Journal of Mathematics Teacher Education, 18(6), 551-575. https://doi.org/10.1007/s10857014-9294-3

Moyer, P. S., \& Milewicz, E. (2002). Learning to question: Categories of questioning used by preservice teachers during diagnostic mathematics interviews. Journal of Mathematics Teacher Education, 5(4), 293-315. https:/ / doi.org/10.1023/ A:1021251912775

Munthe, E., \& Rogne, M. (2015). Research based teacher education. Teaching and Teacher Education, 46, 17-24. https://doi.org/10.1016/j.tate.2014.10.006

National Council of Teachers of Mathematics [NCTM] (2014). Principles to actions: Ensuring mathematical success for all. Reston, VA: Author.

Parkinson, P. T. (2009). Field-based preservice teacher research: facilitating reflective professional practice. Teaching and Teacher Education, 25(6), 798-804. https:// doi.org/10.1016/j.tate.2008.11.017

Peterson, B. E., \& Leatham, K. R. (2009). Learning to use students' mathematical thinking to orchestrate a class discussion. In L. Knott (Ed.), The role of mathematics discourse in producing leaders of discourse (pp. 99-128). Charlotte, NC: Information Age Publishing.

Phelps-Gregory, C. M., \& Spitzer, S. M. (2018). Developing prospective teachers' ability to diagnose evidence of student thinking: Replicating a classroom intervention. In T. Leuders, J. Leuders, \& K. Philipp (Ed.), Diagnostic Competence of Mathematics Teachers (pp. 223-240). Switzerland: Springer International Publishing. https:/ / doi.org/10.1007/978-3-319-66327-2_12

Ponte, P., Ax, J., Beijaard, D., \& Wubbels, T. (2004). Teachers' development of professional knowledge through action research and the facilitation of this by teacher educators. Teaching and Teacher Education, 20(6), 571588. https:// doi.org/10.1016/j.tate.2004.06.003

Reis-Jorge, J. (2007). Teachers' conceptions of teacher-research and self-perceptions as enquiring practitioners: A longitudinal case study. Teaching and Teacher Education, 23(4), 402-417. https:/ / doi.org/10.1016/j.tate.2006.12.007

Roller, S. A. (2016). What they notice in video: A study of prospective secondary mathematics teachers learning to teach. Journal of Mathematics Teacher Education, 19(5), 477-498. https:/ / doi.org/10.1007/s10857-015-9307-x

Santagata, R., Zannoni, C., \& Stigler, J. W. (2007). The role of lesson analysis in pre-service teacher education: An empirical investigation of teacher learning from a virtual video-based field experience. Journal of Mathematics Teacher Education, 10(2), 123-140. https:/ / doi.org/10.1007/s10857-007-9029-9

Schack, E., Fisher, M., Thomas, J., Eisenhardt, S., Tassell, J., \& Yoder, M. (2013). Prospective elementary school teachers' professional noticing of children's early numeracy. Journal of Mathematics Teacher Education, 16, 379-397. https:// doi.org/10.1007/s10857-013-9240-9

Seago, N. (2004). Using video as an object of inquiry for mathematics teaching and learning. In J. Brophy (Eds.), Advances in research on teaching: Using video in teacher education (pp. 259-286). Amsterdam: Elsevier.

Sherin, M. G., \& van Es, E. A. (2009). Effects of video club participation on teachers' professional vision. Journal of Teacher Education, 60(1), 20-37. https:/ / doi.org/10.1177/0022487108328155

Sherin, M. G., Jacobs, V. R., \& Philipp, R. A. (2011). Mathematics teacher noticing: Seeing through teachers' eyes. New York, New York: Routledge.

Sherin, M. G., Linsenmeier, K. A., \& van Es, E. A. (2009). Selecting video clips to promote mathematics teachers' discussion of student thinking. Journal of Teacher Education, 60(3), 213-230. https:/ / doi.org/10.1177/0022487109336967

Shulman, J. H. (1992). Teacher-written cases with commentaries: A teacher researcher collaboration. In J. H. Shulman, (Eds.), Case Methods in Teacher Education (pp. 131-155). New York: Teacher College Press.

Souto-Manning, M. (2012). Teacher as researcher: Teacher action research in teacher education. Childhood Education, 88(1), 54-56. https:/ / doi.org/10.1080/00094056.2012.643726

Star, J. R., \& Strickland, S. K. (2008). Learning to observe: Using video to improve preservice mathematics teachers' ability to notice. Journal of Mathematics Teacher Education, 11(2), 107-125. https:/ /doi.org/10.1007/s10857007-9063-7

Stockero, S. L. (2008). Using a video-based curriculum to develop a reflective stance in prospective mathematics teachers. Journal of Mathematics Teacher Education, 11, 373-394. https:/ / doi.org/10.1007/s10857-008-9079-7

Stockero, S. L. (2014). Transitions in prospective mathematics teacher noticing. In J.-J. Lo, K. R. Leatham, \& L. R. Van Zoest (Eds.), Research trends in mathematics teacher education (pp. 239-259). New York: Springer International Publishing. https:/ / doi.org/10.1007/978-3-319-02562-9_13 
Stockero, S. L., \& Van Zoest, L. R. (2013). Characterizing pivotal teaching moments in beginning mathematics teachers' practice. Journal of Mathematics Teacher Education, 16(2), 125-147. https:/ / doi.org/10.1007/s10857012-9222-3

Stockero, S. L., Rupnow, R. L., \& Pascoe, A. E. (2017). Learning to notice important student mathematical thinking in complex classroom interactions. Teaching and Teacher Education, 63, 384-395. https:/ / doi.org/10.1016/j.tate.2017.01.006

Strauss, A., \& Corbin, J. (1990). Basics of qualitative research: Grounded theory procedures and techniques. Newbury Park, CA: Sage Publications.

Superfine, A. C., Fisher, A., Bragelman, J., \& Amador, J. M. (2017). Shifting perspectives on preservice teachers' noticing of children's mathematical thinking. In E. O. Schack, M.H. Fisher, \& J. A. Wilhelm (Eds), Teacher Noticing: Bridging and Broadening Perspectives, Contexts, and Frameworks (pp. 409-426). Springer International Publishing. https://doi.org/10.1007/978-3-319-46753-5_24

Superfine, A. C., Li, W., Bragelman, J., \& Fisher, A. (2015). Examining the use of video to support preservice elementary teachers' noticing of children's thinking. Journal of Technology and Teacher Education, 23(2), 137157.

Teuscher, D., Leatham, K. R., \& Peterson, B. E. (2017). From a Framework to a Lens: Learning to Notice Student Mathematical Thinking. In E. O. Schack, M.H. Fisher, \& J. A. Wilhelm (Eds), Teacher Noticing: Bridging and Broadening Perspectives, Contexts, and Frameworks (pp. 31-48). Springer International Publishing. https://doi.org/10.1007/978-3-319-46753-5_3

Trent, J. (2010). Teacher education as identity construction: Insights from action research. Journal of Education for Teaching, 36(2), 153-168. https:/ / doi.org/10.1080/02607471003651672

van Es, E. A. (2011). A framework for learning to notice student thinking. In M. G. Sherin, V. R. Jacobs, \& R. A. Philipp (Eds.), Mathematics teacher noticing: Seeing through teachers' eyes (pp. 134-151). New York: Routledge.

van Es, E. A., \& Sherin, M. G. (2002). Learning to notice: Scaffolding new teachers' interpretations of classroom interactions. Journal of Technology and Teacher Education, 10(4), 571-596.

van Es, E. A., \& Sherin, M. G. (2008). Mathematics teachers' learning to notice in the context of a video club. Teaching and Teacher Education, 24(2), 244-276. https:// doi.org/10.1016/j.tate.2006.11.005

van Es, E. A., Cashen, M., Barnhart, T., \& Auger, A. (2017). Learning to notice mathematics instruction: Using video to develop preservice teachers' vision of ambitious pedagogy. Cognition and Instruction, 1-23. https:/ / doi.org/10.1080/07370008.2017.1317125

van Es, E. A., Tunney, J., Goldsmith, L. T., \& Seago, N. (2014). A framework for the facilitation of teachers' analysis of video. Journal of Teacher Education, 65(4), 340 -356. https:/ / doi.org/10.1177/0022487114534266

Walkoe, J. (2015). Exploring teacher noticing of student algebraic thinking in a video club. Journal of Mathematics Teacher Education, 18(6), 523-550. https:/ / doi.org/10.1007/s10857-014-9289-0 


\section{APPENDIX 1}

\section{Example Video Segments in MCVC1}

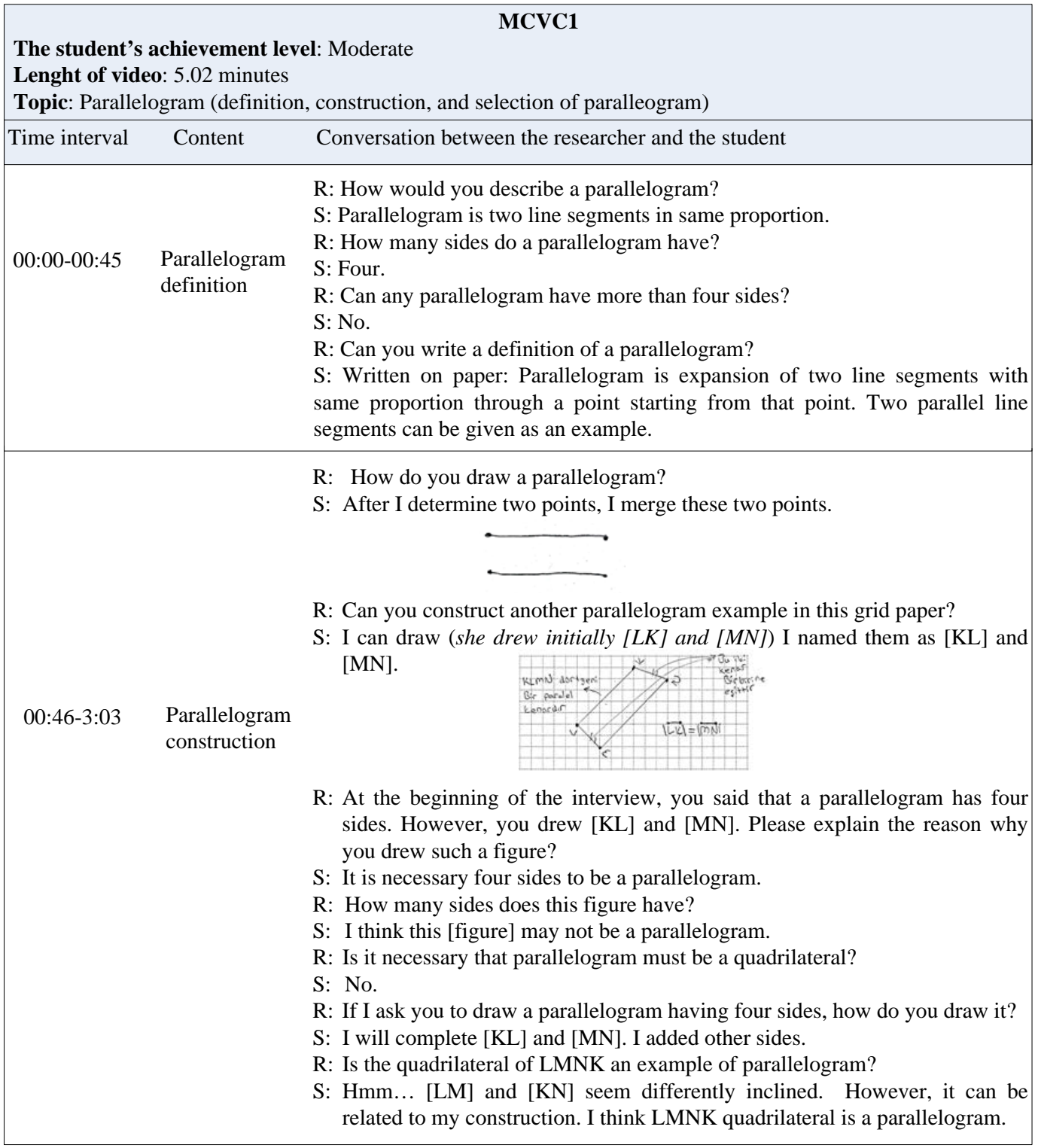

\section{http://www.ejmste.com}

